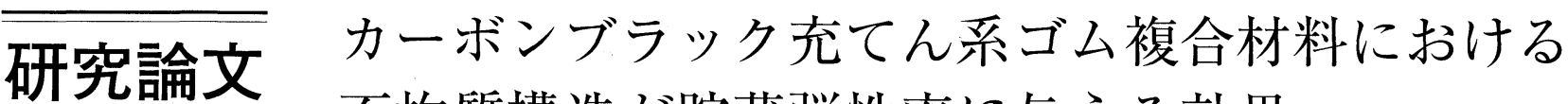 不均質構造が䝪蔵弾性率に与える効果
}

\author{
八柳 史*1 $\cdot$ 伊藤 眞義*1 $・$ 海藤 博幸*2

\section{Effects of Inhomogeneous Structure on the Storage Modulus of Black Filled Rubber Systems}

Fumito Yatsuyanagi, Masayoshi Ito (Department of Chemistry, Faculty of Science, Science University of Tokyo, 1-3 Kagurazaka, Shinjuku-ku, Tokyo 162-8601, Japan), Hiroyuki Kaidou (Research \& Development Center, The Yokohama Rubber Co., Ltd., 2-1 Oiwake, Hiratsuka, Kanagawa 254-8601, Japan)

Temperature dependence of storage modulus was studied as a function of structural changes of black filled rubber systems. Above $10^{\circ} \mathrm{C}$, the storage modulus ( $\left.\mathrm{E}^{\prime}\right)$ of black filled rubber systems decreased with increasing a temperature. The change was dependent on the content and grade of carbon black in the filled rubber systems. NMR results revealed that black filled rubber system had a multi-component system depending on the mobility of rubber molecules, which was a function of temperature. The amount of less mobile rubber component decreased with increasing the temperature without noticeable changes in the mobility. The temperature dependence of the $\mathrm{E}^{\prime}$ was affected by the amount of less mobile rubber molecules which was primarily determined by the specific surface area of carbon black. The relation between occluded rubber structure and less mobile rubber component was also discussed. Based on the results, the structural changes of occluded rubber with temperature were proposed.

(Received on December 7, 1999)

(Accepted on July 16, 2001)

Key Word : Carbon Black, Rubber, Storage Modulus, Spin-Spin Relaxation Time, Occluded Rubber

\section{1. 緒言}

カーボンブラックを添加することにより生じるゴムの補 強効果は, カーボンブラック表面との相互作用で生成した ゴム拘束成分や，カーボンブラック粒子が融着して形成さ れた凝集体の間隙に包蔵されたゴム成分の影響を受けるこ とが知られている1-22). カーボンブラック充てんゴム中 の溶剂不溶なゴム分(バウンドラバー) は分子運動性の異な るいくつかのゴム相からなり, その中に極めて分子運動性 が制限されたゴム相が存在することが，広幅パルス NMR 解析から明らかになっている7-15，17)。こうしたゴム拘束 成分が力学的にフィラーと同様の振る舞いをすることを前 提にして, 補強性との関係が議論されている5，16-18). 我々はこれまで広幅パルス NMRを用いてカーボンブラ ック充てんゴムのバウンドラバー構造について議論して きた ${ }^{7,8,15)}$.その結果, カーボンブラック近辺に存在する ゴム拘束相分率は温度上昇に伴い減少すること ${ }^{7,8.15)}$ を明

\footnotetext{
*1 東京理科大学理学部化学科 ( $\mathrm{T} 162-8601$ 東京都新宿区神楽坂 1-3)

$* 2$ 横浜ゴム(制研究本部研究部 († 254-8601 平塚市追分 2-1)
}

らかにした.これらのことにより, カーボンブラック近辺 に形成される不均質構造の温度による変化が弾性率の温度 依存性に大きく影響を与えていることが予想される。一方， 補強効果はカーボンブラック凝集体中に包蔵されたゴム成 分(オクルードラバー)の量に依存する19-22)ことが知られ ているが, 補強効果の温度依存性とオクルードラバーとの 関係は明らかになっていない. Wang ${ }^{22)}$ はゴム拘束成分 と包蔵されたゴム成分を組み合わせたモデルを提示してい る.しかし, 両成分の相互関係は言及されていない。 カーボンブラック充てんゴムにおける弾性率の温度依存 性は，カーボンブラック表面にゴム分子が束縛されること で生じるガラス転移温度の変化で説明されており 22-24), HAF 級カーボンブラック添加による充てんゴムのガラス 転移温度の変化はゴム 100 重量部に対してカーボンブラッ ク 10 重量部当たり $0.2^{\circ} \mathrm{C}$ と見積もられている ${ }^{24)}$. しかし， 一般に行われているカーボンブラック充てん量でのガラス 転移温度の上昇は 1 〜 ${ }^{\circ} \mathrm{C}$ であり, カーボンブラック充て んゴムの顕著な弾性率の温度依存性を説明するには不十分 であると考えられる。

本研究では, カーボンブラック充てんゴム中のゴム拘束 
相の温度による量的変化と貯蔵弾性率 $\mathrm{E}^{\prime} の$ 温度依存性の関 係を定量的に検討することを目的とした。更に，オクルー ドラバーとゴム拘束相の関係を検討し，オクルードラバー 構造の温度依存性に関するモデルを提案した。

\section{2. 実}

\section{1 試 料}

原料ゴムとして，乳化重合スチレンーブタジエンゴム （Nipol SBR1502：ガラス転移温度 $-52{ }^{\circ} \mathrm{C}$ ）を用いた。原 料カーボンブラックとして, HAF 級 2 種類, SAF 級 1 種 類を用い，それらの特性を Table 1 に示した。測定に用い た試料の配合内容をTable 2 に示した。原料ゴムと，加硫 剂を除く配合剂をバンバリーミキサーで混合して，未加硫 ゴムを得た．未加硫ゴムに硫黄および加硫促進剂をロール ミル上で混練し， 2 〜 mm厚のシートにした.このシー 卜を裁断した細片を $160{ }^{\circ} \mathrm{C} て ゙ 20$ 分間プレス加硫し，寸法 $2 \times 200 \times 200 \mathrm{~mm}$ の加硫ゴムシートを得た．NMR測定に は充てんゴム中にステアリン酸亜鉛や未反応の加硫促進剂 等を含まない試料を用いた。これらの試料は，充てんゴム シートを細断し，アセトンを用いてソックスレー抽出を行 ったあと，室温で減圧乾燥して得た。

バウンドラバー試料は未加硫ゴム中の溶剂可溶分を除去 することで得た。未加硫ゴム分を約 $1 \mathrm{~g}$ 細断し，ワイヤー

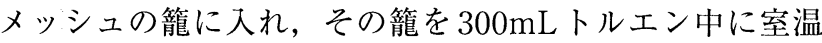
で 72 時間放置した。その後，メッシュ籠中の溶媒不溶分 をアセトンで洗浄し, 室温で減圧乾燥したものをバウンド ラバー試料とした。

Table1 Characteristics of carbon black

\begin{tabular}{c|c|c|c}
\hline & HAF1 & HAF2 & SAF \\
\hline $\mathrm{N}_{2} \mathrm{SA}\left(\mathrm{m}^{2} / \mathrm{g}\right)$ & 83 & 93 & 152 \\
\hline $\mathrm{DBP}(\mathrm{cc} / 100 \mathrm{~g})$ & 75 & 117 & 127 \\
\hline $24 \mathrm{M} 4 \mathrm{DBP}(\mathrm{cc} / 100 \mathrm{~g})$ & 70 & 101 & 114 \\
\hline
\end{tabular}

$\mathrm{N}_{2} \mathrm{SA}\left(\mathrm{m}^{2} / \mathrm{g}\right)$ : Surface area by $\mathrm{N}_{2}$ gas adsorption

$\mathrm{DBP}(\mathrm{cc} / 100 \mathrm{~g})$ : Dibutyl-phthalate adsorption number 24M4DBP (cc/100g) : Dibutyl-phthalate adsorption number of the filler compressed to 24000 psi for 4 times

Table2 Composition of filled rubber system (parts by weight)

\begin{tabular}{|c|c|c|c|c|c|c|c|c|c|c|}
\hline Sample No. & S1 & S2 & S3 & S4 & S5 & S6 & S7 & S8 & S9 & $\mathrm{S} 10$ \\
\hline SBR 1502 & \multicolumn{10}{|c|}{100} \\
\hline Carbon Black & unfilled & \multicolumn{3}{|c|}{ HAF1 } & \multicolumn{3}{|c|}{ HAF2 } & \multicolumn{3}{|c|}{ SAF } \\
\hline Loading & 0 & 30 & 60 & 90 & 30 & 60 & 90 & 30 & 60 & 90 \\
\hline Aromatic Oil & & & & & 10 & & & & & \\
\hline Zinc Oxide & & & & & 3 & & & & & \\
\hline Stearic Acid & & & & & 2 & & & & & \\
\hline Anti-Oxidant $* 1$ & & & & & 3 & & & & & \\
\hline Accelerator $* 2$ & & & & & 1 & & & & & \\
\hline Sulfur & & & & & 2 & & & & & \\
\hline
\end{tabular}

(unit : gram)

*1 : N-(1,3-dimethyl butyl)-N'-phenyl-p-phenylenediamine

$* 2$ : N-cyclohexyl-benzothiazyl-sulfenamid

\section{2 測 定}

2.2.1 バウンドラバー量測定 バウンドラバー量 $\left(G_{t}\right)$ の测定は，セイコ一電子工業製熱重量分析機 （TG/DTA220）を用いて行った。 G $1 \mathrm{~g}$ 当たりのゴム量 $(\mathrm{g} / \mathrm{g})$ として得られ, カーボンブラック 充てん未加硫ゴム中に含まれる原料ゴム $1 \mathrm{~g}$ 当りの量 $(\mathrm{g} / \mathrm{g})$ として算出した.

2.2.2 貯蔵弾性率測定 加硫ゴムの貯蔵弾性率 $\left(\mathrm{E}^{\prime}\right)$ は，東洋精機製作所製の Rheolographsolidを用い，伸長モ ードにて周波数 $20 \mathrm{~Hz}$, 温度 $10{ }^{\circ} \mathrm{C}, 25{ }^{\circ} \mathrm{C}, 55^{\circ} \mathrm{C}, 70{ }^{\circ} \mathrm{C}$, 動歪 $0.2 \%$ およびェ $2 \%$ で測定した。

\subsubsection{NMR 測定 ${ }^{7,8.15)}$ JEOL 製パルス NMRスペク} トロメーター(JNM FSE100)を用いて測定を行った。ソリ ッドエコー法で得られたFID (Free Induction Decay)信号 を式（1）のワイブル関数を用いて処理することでスピンー スピン緩和時間 $\left(\mathrm{T}_{2}\right)$ と各々の成分分率を得た。今回の測 定において，90パルス幅およびパルスインターバル幅は

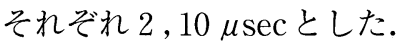

$$
\mathrm{h}(\mathrm{t})=\sum_{1} \mathrm{~h}_{\mathrm{oi}} \exp \left\{-\left(\mathrm{t} / \mathrm{T}_{2 \mathrm{i}}\right)^{\mathrm{Ei}}\right\}
$$

ここで，Eiはワイブル係数， $\mathrm{h}_{\mathrm{oi}}$ は $\mathrm{t}=0$ における $\mathrm{i}$ 成 分の信号強度で， $\mathrm{T}_{2 \mathrm{i}}$ は $\mathrm{i}$ 成分のスピンースピン緩和時間で ある。 $\mathrm{T}_{2 \mathrm{i}}$ が $\mathrm{j}$ 個に分離されるときの $\mathrm{j}$ 番目の成分分率 $\left(F_{\mathrm{j}}\right)$ は次式 $(2)$ で与えられる.

$$
\mathrm{F}_{\mathrm{j}}=\mathrm{h}_{0 \mathrm{i}} / \sum_{\mathrm{i}} \mathrm{h}_{0 \mathrm{j}}
$$

加硫ゴムにおける各成分量は式 (2) から得られる成分分 率をゴム $1 \mathrm{~mL}$ あたりの量 $\mathrm{fj}(\mathrm{mL} / \mathrm{mL})$ に換算することで 得られた。なお， $\mathrm{T}_{2}$ および $\mathrm{F}_{\mathrm{j}}$ の実験誤差はそれぞれ土 $3 \%$ よびェ $5 \%$ であった。

\section{3. 結果および考察}

\section{1 カーボンブラック充てんゴムの貯蔵弾性率}

Fig. 1 は, 各試料 $(\mathrm{S} 2 \sim \mathrm{S} 4, \mathrm{~S} 7, \mathrm{~S} 10)$ における敗蔵弾性 率 $\mathrm{E}^{\prime}$ 温度依存性を示したものである。0 ${ }^{\circ} \mathrm{C}$ 以上のゴム状 領域において，温度上昇に伴う $\mathrm{E}^{\prime}$ の低下はカーボンブラッ クを添加することにより顕著となり，その程度はカーボン ブラック種および充てん量に依存していることがわかる. 一方，未充てんゴム (S1)の $\mathrm{E}^{\prime} も$ 温度上昇に伴い低下する が，その変化は微少である. HAF 級カーボンブラック添 加による充てんゴムのガラス転移温度の変化はゴム 100 重 量部に対してカーボンブラック 10 重量部あたり $0.2^{\circ} \mathrm{C}$ と見 積もられている ${ }^{29)}$. 本研究におけるカーボンブラック充 てん量の最大はゴム 100 重量部に対して 90 重量部であるこ とから, 試料の違いによるガラス転移温度 $\left(\mathrm{T}_{\mathrm{g}}\right)$ の差は最 大でも約 $2{ }^{\circ} \mathrm{C}$ 以内と考えられる。したがって，Fig. 1 で認 められるカーボンブラック充てん量の違いがE'の温度依存 性に与える影響を Tgの差で説明するには無理があると考 えられる。 


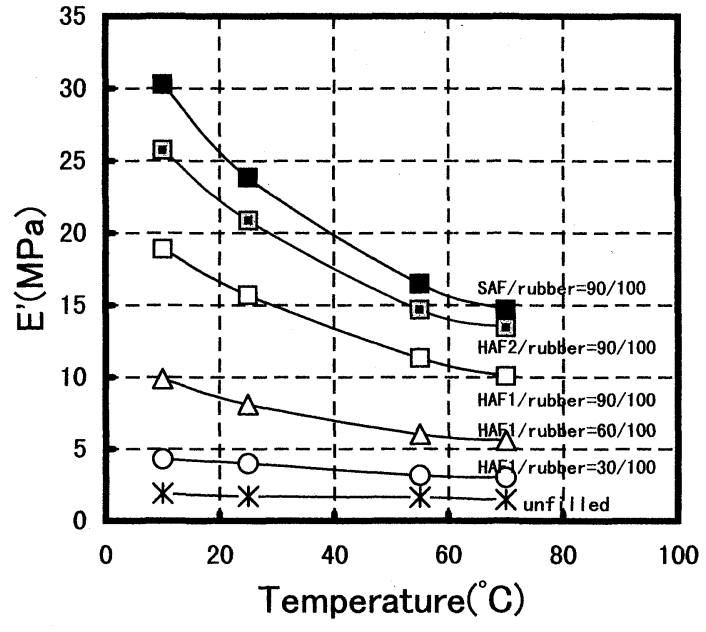

Fig.1 Temperature dependence of $\mathrm{E}^{\prime}$ at DSA of $2 \%$ for black filled and unfilled rubber systems

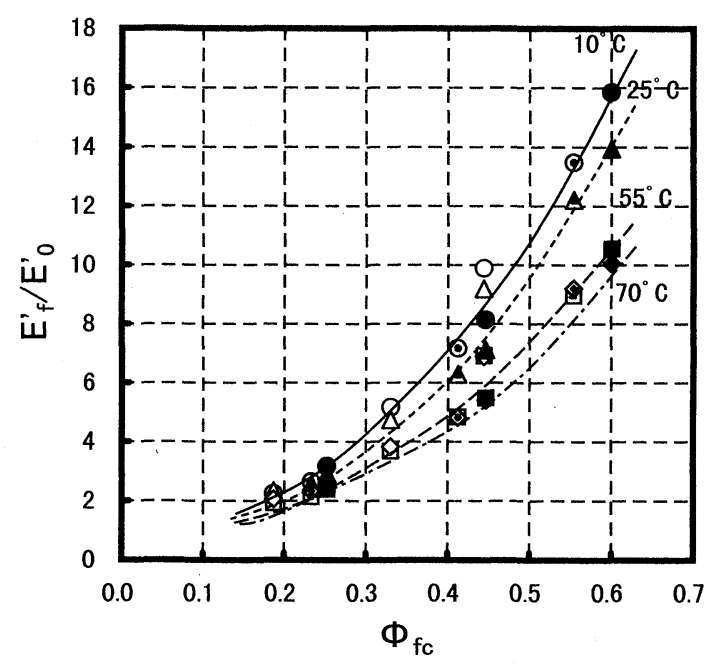

Fig.2 Relation between $\Phi_{\mathrm{fc}}$ and $\mathrm{E}_{\mathrm{f}}^{\prime} / \mathrm{E}_{\mathrm{o}}^{\prime}$ at DSA of $2 \%$ (open: HAF1 grade carbon black, dotted: HAF2 grade carbon black, filled: SAF grade carbon black)

カーボンブラック等のフィラー添加により充てんゴムの 弾性率は加速度的に増加する。この現象は, ゴム中に弾 性率の高いカーボンブラック部分が増加することでゴム に応力が集中するためと考えられており，フィラー(体 積) 効果 ${ }^{19,25)}$ と呼ばれている.未充てんゴムの貯蔵弾性 率を $\mathrm{E}_{\mathrm{o}}^{\prime}$, カーボンブラック充てんゴムの貯蔵弾性率を $\mathrm{E}_{\mathrm{f}}^{\prime}$, カーボンブラックの体積分率を $\Phi_{\mathrm{f}}$ とすると, 体積効果 $\mathrm{f}$ $\left(\Phi_{\mathrm{f}}\right)$ は式 $(3)$ で表わせる.

$\mathrm{f}\left(\Phi_{\mathrm{f}}\right)=\mathrm{E}_{\mathrm{f}}^{\prime} / \mathrm{E}_{\mathrm{o}}^{\prime}$

なおカーボンブラック充てんゴム中のゴムの体積を $\mathrm{V}_{\mathrm{r}}$, カーボンブラック体積を $\mathrm{V}_{\mathrm{f}}$ とすると， $\Phi_{\mathrm{f}}$ は式 (4)で与え られる。

$\Phi_{\mathrm{f}}=\mathrm{V}_{\mathrm{f}} /\left(\mathrm{V}_{\mathrm{r}}+\mathrm{V}_{\mathrm{f}}\right)$

しかし，カーボンブラックは微小な粒子(パーティクル) が融着した凝集体(アグリゲート)を形成している．アグリ ゲートの間隙に包蔵されたゴム成分 (オクルードラバー)

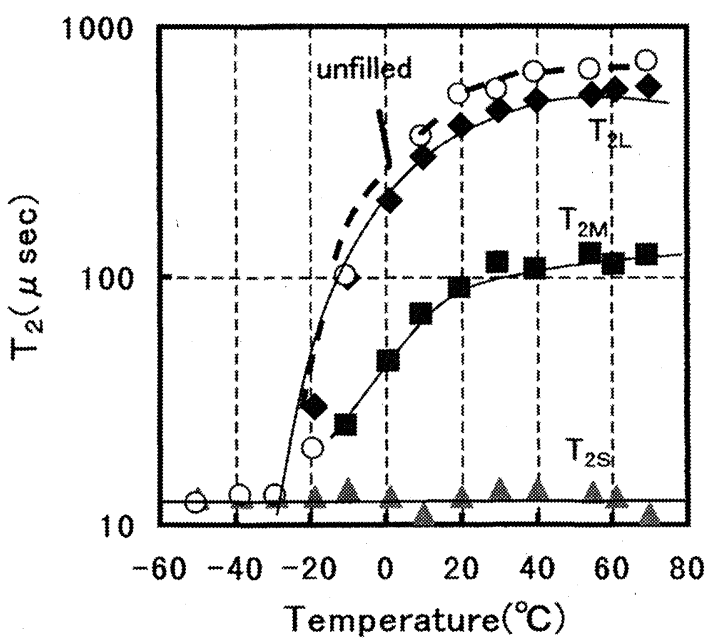

Fig.3 Temperature dependence of $\mathrm{T}_{2}$ for unfilled(S1) and black filled SBR system (S9)

はカーボンブラック充てんゴム中で応力変形を受けにくく ゴムからの排除体積として振舞う19-21）と考えられてい る.Wangらは，カーボンブラックに対する圧縮 DBP 吸 油量 $(\mathrm{CDBP})$ から見積もったオクルードラバー量で $\Phi_{\mathrm{f}}$ を 補正した有効体積分率 $\Phi_{\mathrm{fc}}$ を提示している $(\text { 式 (5) })^{21)}$.

$\Phi_{\mathrm{fc}}=\Phi_{\mathrm{f}} \cdot(1+0.0181 \cdot \mathrm{CDBP}) / 1.59$

Fig. 2 は，カーボンブラック充てんゴム ( S 2 ～S 10) に関して， $\Phi_{\mathrm{fc}}$ に対する $\mathrm{E}_{\mathrm{f}}^{\prime} / \mathrm{E}_{\mathrm{o}}^{\prime}$ の変化をプロットしたもの である。なお，CDBPとして Table 1 に示した24M4DBP 值を用いた，同一温度において $\Phi_{\mathrm{fc}}$ に対する $\mathrm{E}_{\mathrm{f}}^{\prime} / \mathrm{E}_{\mathrm{o}}^{\prime}$ の変化 はカーボンブラック種によらず同一線上に位置しており, 貯蔵弾性率がオクルードラバーを考慮した $\Phi_{\mathrm{fc}}$ の関数であ ることを示している。しかし，Fig. 2 で示された結果には 明確な温度依存性が認められる。Fig. 1 から明らかなよう

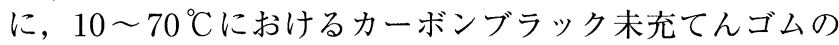
貯蔵弾性率 $\left(\mathrm{E}_{0}^{\prime}\right)$ はほぼ一定值を示していることから，Fig. 2 で認められる $\mathrm{E}_{\mathrm{f}}^{\prime} / \mathrm{E}_{\mathrm{o}}^{\prime}$ の温度依存性はカーボンブラック 充てんゴムの貯蔵弾性率 $\left(\mathrm{E}_{\mathrm{f}}^{\prime}\right)$ の温度依存性に基づくもの である. カーボンブラックのアグリゲート構造は温度によ り変化しないと考えられるゅえ，CDBPも温度に対して一 定であり，その結果，オクルードラバー量も測定温度範囲 内では一定と考えられる。これらのことは， $\mathrm{E}_{\mathrm{f}}^{\prime}$ の温度依 存性がカーボンブラック近辺に形成されたゴムの高次構造 が温度によって変化したことと関連があることを示唆して いる.

\subsection{NMRによる高次構造解析}

パルス NMR 法はゴム分子鎖の運動性の違いや多相構造 物の相分率に関する情報を提供してくれる。カボンブラ ック充てんゴムの運動性に関する情報を得るために，試料 の NMRソリッドェコー法によるFID信号の温度依存性を 测定し，式(1)および (2)を用いて信号解析を行った。 Fig. 3 はカーボンブラック未充てんゴム (S1) および, カーボ 


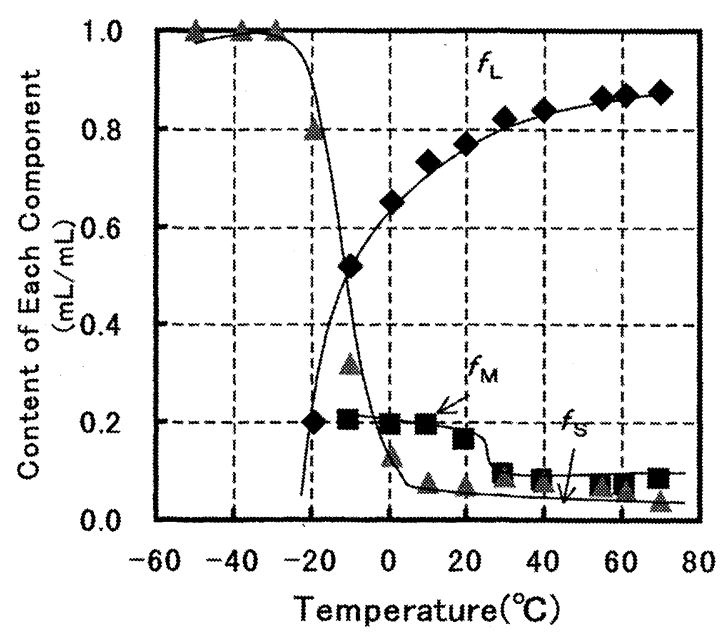

Fig.4 Temperature dependence of the content of each component for black filled SBR system (S9)

ンブラック充てんゴム (S9) についてスピンースピン緩和時 間 $\left(\mathrm{T}_{2}\right)$ の温度依存性を示したものである.未充てんゴム の $\mathrm{T}_{2}$ は, $-30{ }^{\circ} \mathrm{C}$ 以下において約 $20 \mu \mathrm{s}$ と非常に短く, ゴ ム分子の運動性がかなり強い束縛状態にあることを示して いる. 温度上昇に伴い $\mathrm{T}_{2}$ は長くなり $80^{\circ} \mathrm{C}$ では約 $800 \mu \mathrm{sec}$ となる. 伊藤らは未充てんゴム加硫物において, 高温にお いても運動性の低い成分が検出され, それがステアリン酸 亜鉛の信号であることを報告している ${ }^{26)}$. 本研究で用い た試料は, アセトン抽出によりステアリン酸覀鉛成分が除 去されており, その結果, 未充てんゴム $(\mathrm{S} 1)$ の $\mathrm{T}_{2}$ は, 単 一成分からなることが確認された。一方，カーボンブラッ ク充てんゴム $(\mathrm{S} 9)$ の $\mathrm{T}_{2}$ は, $-30{ }^{\circ} \mathrm{C}$ 以下では未充てんゴム 配合と同様, 約 $20 \mu \mathrm{sec}$ の值を示すが, 高温領域では緩和 時間の異なる 3 種の $\mathrm{T}_{2}$ 成分 $\left(\mathrm{T}_{2 \mathrm{~L}}, \mathrm{~T}_{2 \mathrm{M}}, \mathrm{T}_{2 \mathrm{~S}}\right)$. が観測され た. 3 つの $\mathrm{T}_{2}$ 成分に対応する各相の量 $\left(\mathrm{f}_{\mathrm{L}}, \mathrm{f}_{\mathrm{M}}, \mathrm{f}_{\mathrm{S}}\right)$ の温 度依存性を Fig. 4 に示す。温度上昇に伴い緩和時間の長い $\mathrm{T}_{2 \mathrm{~L}}$ の成分量 $\mathrm{f}_{\mathrm{L}}$ は増加し, 緩和時間の短い $\mathrm{T}_{2 \mathrm{M}}$ と $\mathrm{T}_{2 \mathrm{~S}}$ の成 分量 $\mathrm{f}_{\mathrm{M}}$ と $\mathrm{f}_{\mathrm{S}}$ は減少した. カーボンブラック充てんゴムに おける $10^{\circ} \mathrm{C}$ 以上での $\mathrm{T}_{2 \mathrm{M}}$ は未充てんゴムにおける $-20^{\circ} \mathrm{C}$ から $-10{ }^{\circ} \mathrm{C}$ の $\mathrm{T}_{2}$, 更に $\mathrm{T}_{2 \mathrm{~S}}$ は未充てんゴムにおけるガラ ス状態における $\mathrm{T}_{2}$ に対応しており， $\mathrm{T}_{2 \mathrm{M}}$ と $\mathrm{T}_{2 \mathrm{~S}}$ に対応する 分子運動性は $\mathrm{T}_{2 \mathrm{~L}}$ のそれに比較して極端に低い。このこと は, $\mathrm{T}_{2 \mathrm{M}}, \mathrm{T}_{2 \mathrm{~S}}$ に対応するゴム成分が $\mathrm{T}_{2 \mathrm{~L}}$ に比べて硬い樹 脂状に近い状態にあると考えられる.すなわち， T $2 \mathrm{M}$ 相と $\mathrm{T}_{2 \mathrm{~S}}$ 相はカーボンブラック近傍で運動が強固に拘束された ゴム相であり， $\mathrm{T}_{2 \mathrm{~L}}$ 相に比較してかなり大きな弾性率を有 する成分であると考えられる。 そこで， $\mathrm{T}_{2 \mathrm{M}}$ 相と $\mathrm{T}_{2 \mathrm{~S}}$ 相が 補強性に関与していると考え，2つの相を合わせて $\mathrm{T}_{2 \mathrm{M}+\mathrm{S}}$ 相として扱った。

\section{3 ゴム拘束相と貯蔵弾性率の関係}

Fig. 5 は分子運動が高度に拘束されたゴム成分 $\left(\mathrm{T}_{2 \mathrm{M}+\mathrm{S}}\right.$ 相) の量 $\mathrm{f}_{\mathrm{M}}$ および $\mathrm{f}_{\mathrm{S}}$ の和 $\mathrm{f}_{\mathrm{M}+\mathrm{S}}$ を温度に対してプロットしたも

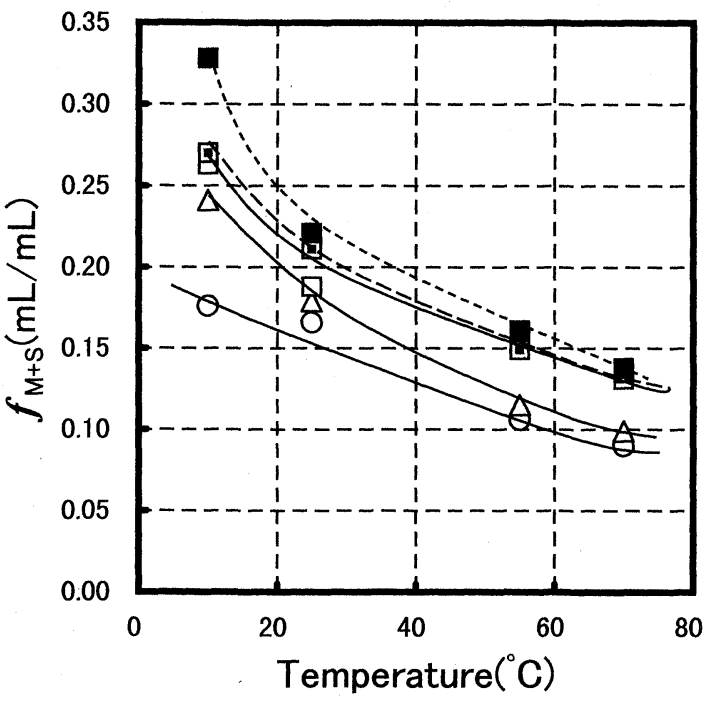

Fig.5 Temperature dependence of $f_{M+S}$ for black filled SBR systems (open: HAF1 grade carbon black, dotted: HAF2 grade carbon black, filled: SAF grade carbon black, circle: carbon black $/$ rubber $=30 / 100$, triangle: carbon black $/$ rubber $=$ $60 / 100$, square: carbon black $/$ rubber $=90 / 100$ )

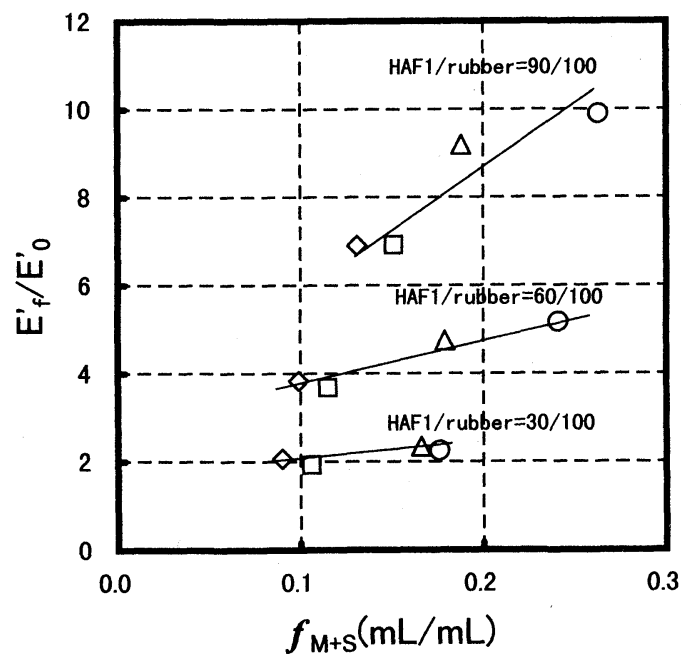

Fig.6 Relation between $\mathrm{f}_{\mathrm{M}+\mathrm{S}}$ and $\mathrm{E}_{\mathrm{f}}^{\prime} / \mathrm{E}_{0}^{\prime}$ at DSA of $2 \%$ for black filled SBR systems (circle: $10{ }^{\circ} \mathrm{C}$, triangle: $25^{\circ} \mathrm{C}$, square: $55^{\circ} \mathrm{C}$, rhomb: $70^{\circ} \mathrm{C}$ )

のである. $10{ }^{\circ} \mathrm{C} に お け る \mathrm{f}_{\mathrm{M}+\mathrm{S}}$ は $0.18 〜 0.33(\mathrm{~mL} / \mathrm{mL})$ と大 きな值を示すが,この值は温度上昇に伴い急激に減少する. 前述のように $\mathrm{f}_{\mathrm{M}+\mathrm{S}}$ は充てんゴム試料の弾性率に大きな影響 を与えていると考えられるので試料 S 2 〜 S 4 について $\mathrm{f}_{\mathrm{M}+\mathrm{S}}$ と $\mathrm{E}_{\mathrm{f}}^{\prime} / \mathrm{E}_{\mathrm{o}}^{\prime}$ との対応を試み，その結果を Fig. 6 に示した. 一定のカーボン充てん量において, 温度変化による $\mathrm{E}_{\mathrm{f}}^{\prime} / \mathrm{E}^{\prime}$ の変化は $\mathrm{f}_{\mathrm{M}+\mathrm{S}}$ の変化とよく相関している．このことは $\mathrm{f}_{\mathrm{M}+\mathrm{S}}$ の温度変化が貯蔵弾性率の温度依存性に大きく影響を与え ていることを示している. Fig. 7 は充てんされたカーボン ブラックの比表面積 $\mathrm{A}$ とゴム $1 \mathrm{~g}$ あたりのカーボンブラッ ク充てん量 $\mathrm{W}_{\mathrm{f}}$ の積と, いくつかの温度における $\mathrm{f}_{\mathrm{M}+\mathrm{S}}$ に対し てプロットしたものである。いずれの温度においても， $\mathrm{f}_{\mathrm{M}+\mathrm{S}}$ はゴム $1 \mathrm{~g}$ あたりのカーボンブラック表面積 $\left(\mathrm{A} \times \mathrm{W}_{\mathrm{f}}\right)$ 


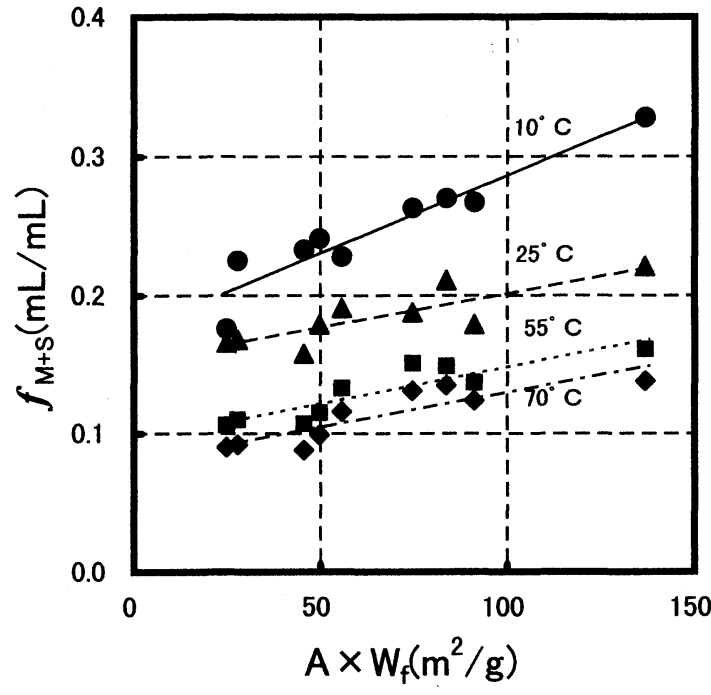

Fig.7 Relation between $\mathrm{A} \times \mathrm{W}_{\mathrm{f}}$ and $\mathrm{f}_{\mathrm{M}+\mathrm{S}}$ of black filled SBR systems

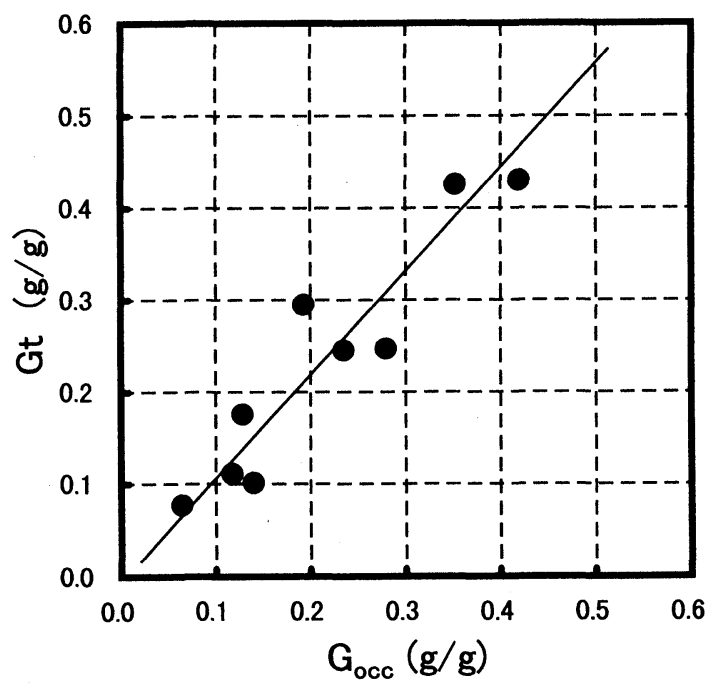

Fig.8 Relation between $\mathrm{G}_{\text {occ }}$ and $\mathrm{G}_{\mathrm{t}}$ for black filled SBR systems

の増加とともに増加して抢り, 拘束された $\mathrm{T}_{2 \mathrm{M}+\mathrm{S}}$ 相がカー ボンブラック表面に形成されることを示している.

\section{4 オクルードラバーとバウンドラバーの関係}

オクルードラバーは, カーボンブラックの構造のみに起 因する概念であり，その量はカーボンブラックに対する DBP吸油量で見積もられる19-21)。一方，バウンドラバー は未加硫カーボンブラック充てんゴムの溶剤抽出不溶分と して見積もられ，カーボンブラックとの相互作用により形 成された結合ゴム成分と考えられている ${ }^{7,8,11,12,14,15)}$. Dannenberg ${ }^{3)}$ は，カーボンブラック単位表面積あたりのバウ ンドラバー量から推定して，大きいアグリゲートをもつカ ーボンブラックほどバウンドラバー量は多いことを示して いる。このことは，DBP吸油量が多いほどバウンドラバ 一量が多いことを意味している．Fig. 8 は，各カーボンブ ラック種拉よび各充てん量に扔けるオクルードラバー量 $\mathrm{G}_{\mathrm{occ}}$ に対してバウンドラバー量 $\mathrm{G}_{\mathrm{t}}$ をプロットしたものであ

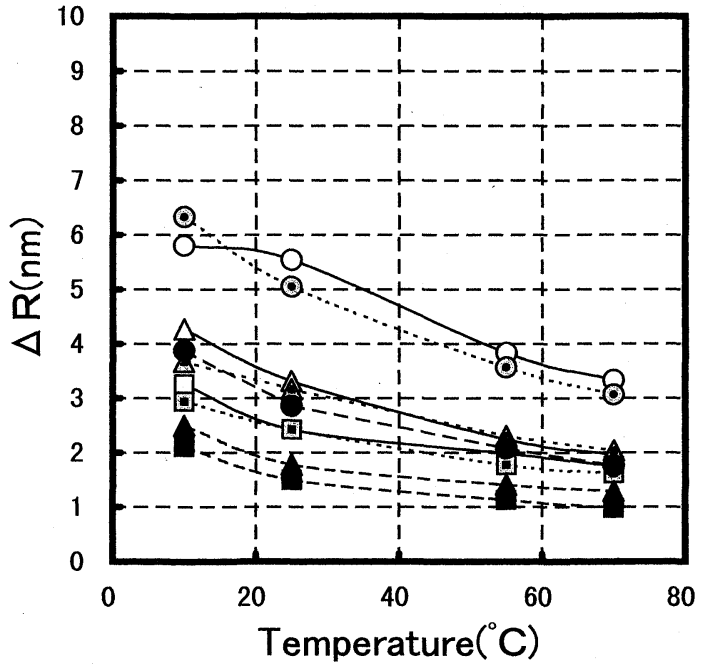

Fig.9 Temperature dependence of the average thickness of $\mathrm{T}_{2 \mathrm{M}+\mathrm{S}}$ phase $(\Delta \mathrm{R})$ for black filled SBR systems (open: HAF1 grade carbon black, dotted: HAF2 grade carbon black, filled: SAF grade carbon black, circle: carbon black/rubber $=$ $30 / 100$, triangle: carbon black/rubber $60 / 100$, square: carbon black/rubber $=90 / 100)$

る. $\mathrm{G}_{\mathrm{occ}}$ は，式(5)から得られる有効体積分率 $\Phi_{\mathrm{fc}}$ からカー ボンブラックの体積分率 $\Phi_{\mathrm{f}}$ を差し引き，それをゴム $1 \mathrm{~g}$ あ たりの量 $(\mathrm{g} / \mathrm{g})$ に換算することで得られ，式(6)で表され る.

$$
\mathrm{G}_{\text {occ }}=\rho_{\mathrm{r}} \cdot\left(\mathrm{V}_{\mathrm{r}} \cdot \mathrm{V}_{\mathrm{f}}\right) / \mathrm{V}_{\mathrm{r}} \cdot\{(1+0.0181 \cdot \mathrm{CDBP}) / 1.59-1\}
$$

ここで， $V_{\mathrm{r}}$ はカーボンブラック充てんゴム中のゴムの 体積， $\mathrm{V}_{\mathrm{f}}$ はカーボンブラック体積， $\rho_{\mathrm{r}}$ はゴムの密度であ る. Fig. 8 から明らかなように，オクルードラバー量 $\mathrm{G}_{\mathrm{occ}}$ とバウンドラバー量 $\mathrm{G}_{\mathrm{t}}$ は非常に良い相関関係が得られて いる.このことは，バウンドラバーとオクルードラバーが 類似の構造体であることを示唆している. バウンドラバー は，ゴム分子運動性の異なる多相構造を有しており，そ の構造がバウンドラバー量に依存することが報告され ている ${ }^{8,15)}$ 。それゆえ，オクルードラバーも，バウンド ラバー同様の多相構造を有している可能性がある.

\section{5 オクルードラバー構造の温度依存性}

バウンドラバーの $\mathrm{T}_{2 \mathrm{M}+\mathrm{S}}$ 相がカーボンブラック表面に均 一の厚さ $\Delta \mathrm{R}$ で存在すると仮定すると， $\Delta \mathrm{R}$ は式 (7)で表 される。

$\Delta \mathrm{R}=\mathrm{f}_{\mathrm{M}+\mathrm{S}} /\left(\Phi_{\mathrm{f}} \cdot \rho_{\mathrm{f}} \cdot \mathrm{A}\right)$

ここで $\rho_{\mathrm{f}}$ と A はカーボンブラックの密度と表面積であ る. Fig. 9 はカーボンブラック充てんゴム (S 2 ～S 10)に おける $\Delta \mathrm{R}$ の温度依存性を示したものである。今回用いた カーボンブラックの場合， $10{ }^{\circ} \mathrm{C}$ から $70{ }^{\circ} \mathrm{C}$ の温度領域にお いて $\Delta \mathrm{R}$ は $1 \mathrm{~nm}$ から $6 \mathrm{~nm}$ の範囲であり，カーボンブラ ック粒子径 $(20 \mathrm{~nm} \sim 27 \mathrm{~nm})$ よりかなり小さい.このこと はアグリゲート構造の間隙に存在する $\mathrm{T}_{2 \mathrm{M}+\mathrm{s}}$ 相の量がオク 


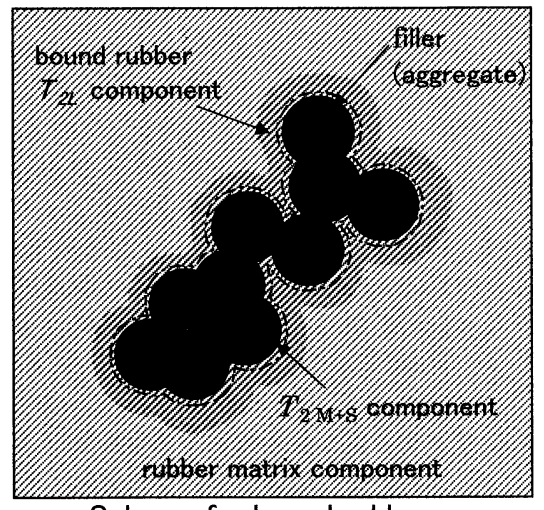

Scheme for bound rubber

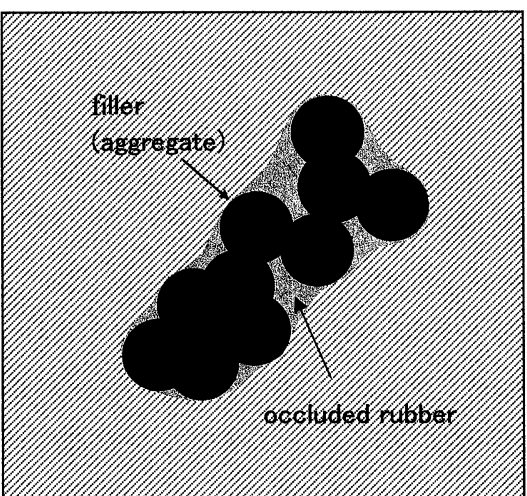

Scheme for occluded rubber

Fig.10: Schematic representation of occluded rubber and bound rubber in black filled rubber system

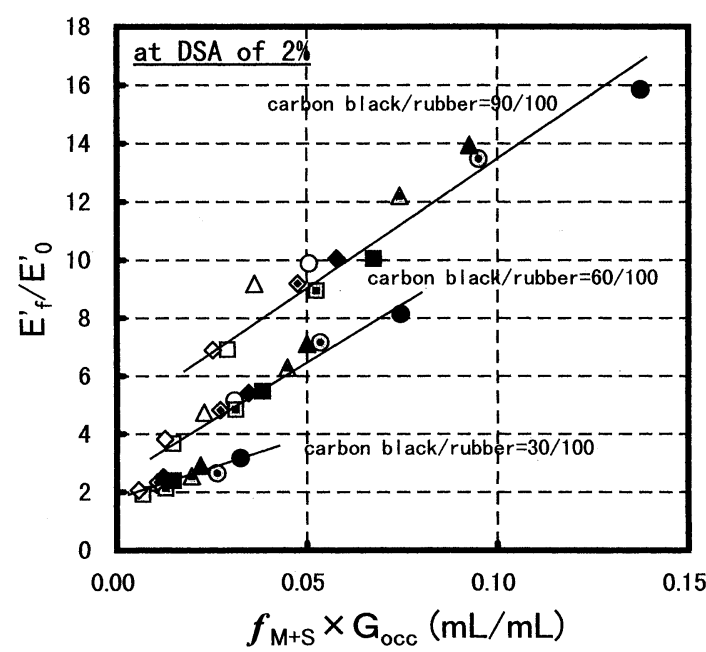

Fig.11 Relation between $\mathrm{f}_{\mathrm{M}+\mathrm{S}} \times \mathrm{G}_{\mathrm{occ}}$ and $\mathrm{E}_{\mathrm{f}}^{\prime} / \mathrm{E}_{0}^{\prime}$ at DSA of $2 \%$ DSA for black filled SBR systems (open: HAF1 grade carbon black, dotted: HAF2 grade carbon black, filled: SAF grade carbon black, circle: $10{ }^{\circ} \mathrm{C}$, triangle: $25^{\circ} \mathrm{C}$, square: $55^{\circ} \mathrm{C}$, rhomb: $70^{\circ} \mathrm{C}$ )

ルードラバー量より少ないことを示唆している.それゆえ， ゴム/カーボンブラック界面に扔ける， $\mathrm{T}_{2 \mathrm{M}+\mathrm{S}}$ 相，オクル ードラバーおよびバウンドラバーの関係を示すモデルは前 節の知見に照らし合わせると Fig.10のように示すことがで きる。オクルードラバーはカーボンブラック上の一部に形 成されるのに対し，バウンドラバーはカーボンブラック全 表面に形成されることを考慮すると，バウンドラバー量が オクルードラバー量より多いと推定される。今までのバウ ンドラバー構造解析結果 7 8.11,12.14.15) $は$ は，バウンドラバー 中の運動性の高い成分である $\mathrm{T}_{2 \mathrm{~L}}$ 相が本研究における $\mathrm{T}_{2 \mathrm{M}+\mathrm{S}}$ 相に比べるとカーボンブラック表面から離れて位置 することを明らかにしている。したがって，オクルードラ バー成分はバウンドラバーの一部を含み，純ゴムよりは運 動性が低い状態にあり，更に， $\mathrm{T}_{2 \mathrm{M}+\mathrm{S}}$ 相および $\mathrm{T}_{2 \mathrm{~L}}$ 相から なる構造体とみなせる．また， $\mathrm{T}_{2 \mathrm{M}+\mathrm{S}}$ 相は極めて薄く，硬 いことからひずみ印加によるカーボンブラック 2 次構造の

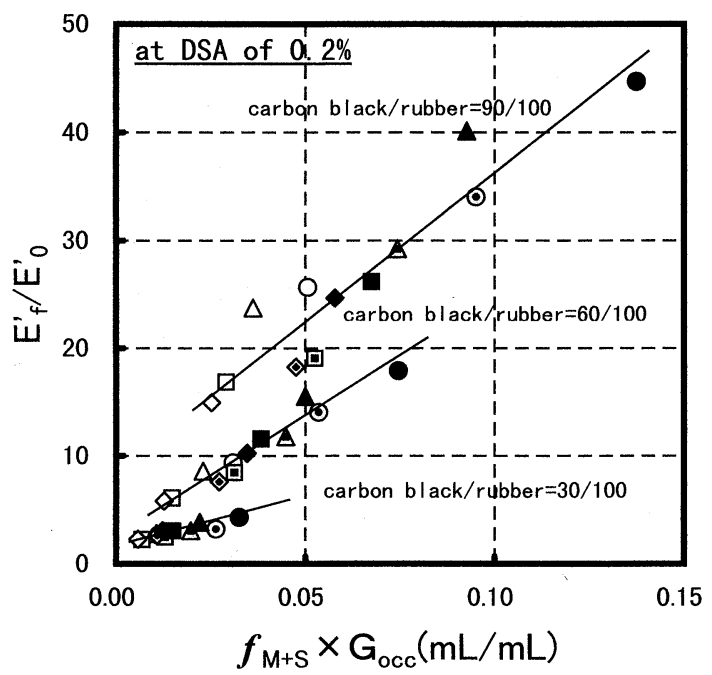

Fig.12 Relation between $\mathrm{f}_{\mathrm{M}+\mathrm{S}} \times \mathrm{G}_{\mathrm{occ}}$ and $\mathrm{E}_{\mathrm{f}}^{\prime} / \mathrm{E}_{\mathrm{o}}^{\prime}$ at DSA of $0.2 \%$ for black filled SBR systems (open: HAF1 grade carbon black, dotted: HAF2 grade carbon black, filled: SAF grade carbon black, circle: $10^{\circ} \mathrm{C}$, triangle: $25^{\circ} \mathrm{C}$, square: $55^{\circ} \mathrm{C}$, rhomb: $70{ }^{\circ} \mathrm{C}$ )

崩壊 27,28) に対して $\mathrm{T}_{2 \mathrm{M}+\mathrm{S}}$ 相の変化は極めて小さいと考え られ，外部から加わる変形に対してカーボンブラック/ゴ ム界面の構造は保たれると考えられる。

オクルードラバー量はカーボンブラックのアグリゲート 構造のみに依存している。 それゅえ, 温度変化に伴いオク ルニドラバー量が変化したとは考えにくい。オクルードラ バーは， $\mathrm{T}_{2 \mathrm{M}+\mathrm{S}}$ 相および $\mathrm{T}_{2 \mathrm{~L}}$ 相からなる構造体とみなせる ことと，過去の知見 ${ }^{7-17)}$ からも毫付けられているように， 補強に関わる有効な成分は運動性の高い成分ではなく強固

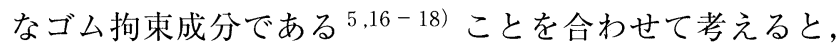
貯蔵弾性率に関与するのはオクルードラバー中の $\mathrm{T}_{2 \mathrm{M}+\mathrm{s}}$ 相 であり，貯蔵弾性率の温度依存性がオクルードラバー構造 の温度変化で説明できると考えた。

カーボンブラック充てんゴムにおけるオクルードラバー 中の $\mathrm{T}_{2 \mathrm{M}+\mathrm{S}}$ 相は，アグリゲート構造の間隙内部に存在する ことから，その量はゴム中のオクルードラバーの成分分率 
に比例し, $\mathrm{f}_{\mathrm{M}+\mathrm{S}}$ 量とオクルードラバーの成分分率との積が その尺度となる．Fig.11および 12 は $\mathrm{f}_{\mathrm{M}+\mathrm{S}}$ とオクルードラ バーの成分分率との積に対して動ひずみ $2 \%$ よび $0.2 \%$ での $\mathrm{E}_{\mathrm{f}}^{\prime} / \mathrm{E}_{\mathrm{o}}^{\prime}$ をプロットしたものである．各充てん量におい て，カーボンブラックの種類および温度に依らず $\mathrm{E}_{\mathrm{f}}^{\prime} / \mathrm{E}_{\mathrm{o}}^{\prime}$ が $\mathrm{f}_{\mathrm{M}+\mathrm{S}}$ とオクルードラバーの成分分率との積に対して同一線 上に位置することがわかる．このことは， $\mathrm{E}_{\mathrm{f}}^{\prime} / \mathrm{E}_{0}^{\prime}$ がオクル ードラバー中の $\mathrm{T}_{2 \mathrm{M}+\mathrm{S}}$ 相の量に依存しており, オクルード ラバー中の $\mathrm{T}_{2 \mathrm{M}+\mathrm{S}}$ 相の量が温度上昇により減少した結果, 貯蔵弾性率の低下をもたらしたものであることを示してい る.

Fig.11および12において，縦軸の絶対值がひずみの違い で大きく異なっているが，これはカーボンブラック充てん ゴムの粘弾性特性のひずみ依存性, いわゆる Payne効果 ${ }^{27}$, 28）に起因するものである。こうした現象は，ゴム中での フィラー 2 次構造形成とその崩壊によると考えられる。し かし，Fig.11および12の結果は， $\mathrm{E}_{\mathrm{f}}^{\prime} / \mathrm{E}_{\mathrm{o}}^{\prime}$ とオクルードラバ 一構造との関係がひずみの大小に依存しないことを示して おり, カーボンブラックの 2 次構造崩填がオクルードラバ 一構造へ与える影響は極めて小さいことを示唆している.

\section{4. 結}

論

カーボンブラック充てんゴムにおいて，広幅パルス NMRにより得られる運動性が拘束されたゴム相に着目 し，ゴム拘束成分とオクルードラバーとの関連性および, カーボンブラック充てんゴムの不均質構造と貯蔵弾性率と の関係について解析したところ以下の知見を得た。

(1) カーボンブラック充てんゴムにおいて, カーボンブラ ック表面に分子運動性が拘束されたゴム拘束相（ $\mathrm{T}_{2 \mathrm{M}+\mathrm{S}}$ 相)が認められ，温度上昇に伴いその量は減少する。

(2) $\mathrm{T}_{2 \mathrm{M}+\mathrm{S}}$ 相の量はカーボンブラック充てんゴムの貯蔵弾 性率と密接に関連している.

(3) オクルードラバー中の拘束されたゴム相の温度依存性 により，貯蔵弾性率の温度依存性を説明することができ
る。

\section{引用 文 献}

1）占部誠亮：ポリマーダイジェスト, 41, No.7, 88, No.8, 81, No.9, 97, No.10, 91, No.12, 95(1990)

2) Radok, J. R. M., Tai, C. C.: J. Appl. Polym. Sci., 6, 518(1962)

3 ) Dannenberg, E.M. : Rubber Chem. Technol., 41, 1256 (1968)

4 ) Sircar, A. K., Voet, A. : Rubber Chem. Technol., 43, 973(1970)

$5)$ Pliskin, I., Tokita, N. : J. Appl. Polym. Sci., 16, 473(1972)

6 ) Cotton, G. R. : Rubber Chem. Technol., 48, 548(1975)

7 ）八柳 史, 海藤博幸, 伊藤眞義, 日ゴム協誌, 67, 707 (1994)

8 ）八柳 史, 海藤博幸，木田信虎，伊藤眞義，日ゴム協誌， 70 , 274 (1997)

9 ) Nishi, T. : J. Polym. Sci., Polym. Phys. Ed., 12, 685(1974)

10) Kaufman, S., Slicter W. P., Daivis, D. D. : J. Polym. Sci. A-2, 9, 829(1976)

11) O'Brien, J., Cashel, E., Wardell, G. E., McBrierty, V. J. : Maclomolecules, 9, 653(1976)

12) Serizawa, H., Ito, M., Kanamoto, T., Tanaka, K., Nomura, A. : Polym. J., 14, 149 (1982)

13) Ito, M., Nakamura, T., Tanaka, K. : J. Appl. Polym. Sci., 30, 3493 (1985)

14) Kenny, J. K., McBrierty, V. J., Righi, Z., Daglass, D. C. : Maclomolecules, 24, 436 (1991)

15) Kida, N., Ito, M., Yatsuyanagi, F., Kaidou, H. : J. Appl. Polym. Sci., 61, 1345(1996)

16) Tokita, N., Shieh, C-H., Ouyang, G. B., Patterson, W. J. : KGK Kaut. Gum., 47, 416 (1994)

17) Asai, S., Kanei, H., Sumita, M., Miyasaka, K. : J. Appl. Polym. Sci., 43, 1253(1991)

18) Eggers, H., Schummer, P. : Rubber Chem. Technol., 69, 253(1996)

19) Medalia, A. I. : J. Colloid Interface Sci., 32, 115(1970)

20) Kraus, G. : Rubber Chem. Technol., 44, 199(1971)

21) Wang, M.-J., Wolff, S., Tan, E. H. : Rubber Chem. Technol., 66, 178 (1993)

22) Wang, M.-J. : Rubber Chem. Technol., 71, 520 (1998)

23）藤本邦彦，西敏夫，日ゴム協誌，43, 54(1970)

24) Kraus, G., Gruver, J. T. : J. Polym. Sci., A-2, 8, 571(1970)

25) Guth, E. : J. Appl. Phys., 16, 20 (1945)

26）伊藤真義，田中公二，宇田川好隆：日ゴム協誌，59, 39（1986)

27) Payne, A. R. : "Dynamic Properties of Filler-Loaded Rubbers" in Reinforcement of Elastomers, G. Kraus, Ed., Interscience, New York (1965), p.69

28) Kraus, G. : J. Appl. Polym. Sci. : Applied Polymer Symposium 39, 75 (1984) 